\title{
Functional Alteration of the Somatotrophic Axis in Transgenic Mice with Liver-Specific Expression of Human Insulin-like Growth Factor Binding Protein-1
}

\author{
DANIELLE SEURIN, PASCAL FROMENT, MARIE-THÉRÈSE BLUET-PAJOT, \\ JACQUES EPELBAUM, PHILIPPE MONGET, AND MICHEL BINOUX
}

Institut National de la Santé et de la Recherche Médicale [INSERM U.515] Hôpital Saint Antoine, 75012

Paris [D.S., M.B.], INSERM U.549, Hôpital Saint Anne, 75013 Paris [M.-T.B.-P., J.E.] and Institut

National de la Recherche Agronomique [IUMR 6073$] 37380$ Nouzilly [P.F., P.M.], France.

\begin{abstract}
ABST
In earlier work, postnatal growth restriction (more marked in
males) was observed in a model of transgenic mice with liver-
specific expression of human IGF binding protein-1. This was
associated with diminished plasma IGF-I levels, the cause of
which remained unexplained. Subsequently, abnormalities of
CNS development were ascertained, justifying investigation of
the somatotrophic axis. Pituitary gland weight in transgenic
animals was reduced proportionally to body weight. Immunohis-
tochemical examination of the pituitaries in $3-$ to 4 -mo-old mice
revealed somatotrophs of normal size in homozygotes, but den-
sity was decreased to approximately two thirds of that in wild-
type siblings $(p=0.001)$. The same was true of lactotrophs. The
GH content of the pituitary was significantly reduced in het-
erozygotes $(p<0.02)$ and more so in homozygotes ( $p<0.0003$ ),
although the GH/total protein ratio was similar to that in wild
types. Pituitary perifusion experiments showed that in vitro the
amounts of GH secreted under basal conditions and under GH-
releasing hormone stimulation were similar in transgenic and
\end{abstract}
A model of transgenic mouse was established in our laboratory, with liver-specific expression of hIGFBP-1 under the control of the $\alpha_{1}$-antitrypsin promoter. The repercussions of this expression, which begins during fetal life, were particularly marked among homozygotes in one of the lines. The signs included reproductive abnormalities, a high incidence of anteand perinatal mortality, and postnatal growth restriction that was more pronounced in males (1).

Received October 29, 2001; accepted January 25, 2002

Correspondence and reprint requests: Michel Binoux, MD, INSERM U.515, Hôpital Saint Antoine, 185 rue du Faubourg Saint Antoine, 75571 Paris Cedex 12, France; e-mail: U515@st-antoine.inserm.fr

Supported by the Institut National de la Santé et de la Recherche Médicale (INSERM) and the Institut National de la Recherche Agronomique (INRA).

DOI: $10.1023 / 01 . P D R .0000019550 .58488 .53$ wild-type mice. Ten days of treatment with human GH (100 $\mu \mathrm{g} / \mathrm{d})$ in 45 -d-old transgenic and wild-type mice provoked significant weight gain $(p=0.02)$ in all animals, the means being $12.4 \%$ for homozygotes and $10.4 \%$ in heterozygotes, as opposed to $5.8 \%$ in wild-type mice. The increase in weight tended to correlate with an increase in plasma IGF-I. From these results, we conclude that the reduced plasma IGF-I in IGF binding protein-1 transgenic mice may result from insufficient GH production by the depressed number of somatotrophs, possibly associated with functional alteration of hypothalamic control.

(Pediatr Res 52: 168-174, 2002)
Abbreviations
IGFBP, IGF binding protein
hIGFBP, human IGF binding protein
GHRH, GH releasing hormone
ALS, acid-labile subunit
DAB, 3,3'-diaminobenzidine tetrahydrochloride dihydrate

Plasma concentrations of hIGFBP-1 resulting from expression in the liver, the normal site of synthesis, remained within the physiologic range $(3.0 \pm 0.4 \mathrm{ng} / \mathrm{mL}$ in heterozygotes, 13.7 $\pm 1.4 \mathrm{ng} / \mathrm{mL}$ in homozygotes), but at constant levels, without the insulin-dependent fluctuations seen in the normal state (2). Although IGFBP-1 levels in the transgenic mice were low, they were higher than those in wild-type animals in which the strong signal in Western ligand blotting during the perinatal period was no longer detectable beyond the age of $6 \mathrm{~d}$, unlike that in the transgenic mice (1). It therefore seemed possible that the growth restriction in the transgenic animals resulted from decreased bioavailability of free IGF-I sequestered by IGFBP-1, particularly in view of the unexpected, concomitant, and significant reduction of total plasma IGF-I in adult homozygotes $(370 \pm 75 \mathrm{ng} / \mathrm{mL})$ by almost half compared with 
that in controls $(630 \pm 56 \mathrm{ng} / \mathrm{mL})$, whereas in heterozygotes IGF-I levels were only slightly lower (544 $\pm 95 \mathrm{ng} / \mathrm{mL})(1)$.

It did not seem likely that the reduced IGF-I was attributable to enhanced clearance. IGFBP-3 concentrations estimated from Western ligand blotting were in normal proportion to IGF-I, which, in largest part, is associated with IGFBP-3 and the ALS in $150-\mathrm{kD}$ complexes that do not cross the capillary endothelium (3). The ALS, which is GH-dependent, could not be measured in these mice, but it has been demonstrated that even in GH-deficient rats, the ALS circulates in excess (4). IGFBP-2 and IGFBP-4 are also capable of forming short-lived binary complexes with IGF-I. However, their concentrations in the transgenic mice were similar to those in wild types as determined by ligand blotting, and in all cases were very low compared with those of IGFBP-3 (1).

The decrease in IGF-I was surprising, in that oversecretion of $\mathrm{GH}$ would have seemed more probable, resulting from depression or suppression by excess IGFBP-1 of the IGF-Imediated negative feedback on GH secretion (5). There were two possible explanations: either IGFBP-1 exerted inhibitory effects on hepatic IGF-I synthesis, both peptides being produced by hepatocytes (6), or IGFBP-1 damaged the hypothalamo-pituitary system, considering the anomalies of CNS development affecting the cerebral cortex, corpus callosum, and hippocampus subsequently discovered in the transgenic mice (7). The present study was undertaken to identify the point(s) at which the somatotrophic axis is affected, to account for the depressed plasma IGF-I and growth restriction.

\section{METHODS}

Animals and biologic samples. Transgenic B6/CBA mice carrying the human $\alpha_{1}$-antitrypsin promoter fused to hIGFBP-1 cDNA have been described elsewhere (1). Northern blotting revealed transgene expression exclusively in the liver during fetal life and unchanged through to adulthood. Between the two lines obtained initially, line 149 exhibited more developmental abnormalities, the severity of which was directly related to the level of transgene expression. This was the line subjected to further investigation. Heterozygous and homozygous animals and nontransgenic litter mates were identified on the basis of Southern blot analyses of DNA samples from tail biopsies (1).

Pituitaries were excised after decapitation of 3- to 4-mo-old mice for purposes of GH measurement, immunohistochemical analysis, and perifusion experiments.

Six-week-old mice were treated with GH (hGH Norditropine, $24 \mathrm{U} / \mathrm{mg}$, NovoNordisk, Bagswaerd, Denmark). Blood samples for the IGF-I assays were taken by intraorbital puncture and collected in tubes rinsed with 0.1M EDTA. Plasma samples were stored at $-20^{\circ} \mathrm{C}$.

All protocols were approved by the institutional review committee.

Pituitary immunohistochemistry. Rabbit antibodies against rat prolactin and rat GH (which cross-react well in the mouse) were kindly provided by A.F. Parlow (NIDDK, Bethesda, MD, U.S.A.) and J. Trouillas (Lyon, France), respectively. Goat peroxidase-labeled antibody against rabbit $\operatorname{IgG}$ was purchased from Interchim (Montlucon, France) and DAB from Aldrich Chimie (L'Isle d'Albeau Chesnes, France).

Pituitaries embedded in paraffin were serially sectioned at a thickness of $10 \mu \mathrm{m}$. Sections were incubated for $30 \mathrm{~min}$ in PBS containing $0.3 \% \mathrm{H}_{2} \mathrm{O}_{2}$ to remove endogenous peroxidase activity and then incubated for 15 min in PBS containing 7\% sheep serum to saturate nonspecific binding sites. Thereafter, they were incubated overnight at $4^{\circ} \mathrm{C}$ with PBS containing $0.1 \%$ BSA and either anti-rat prolactin antibody $(1: 40,000)$ or anti-rat GH antibody $(1: 2,000)$. After washing, the sections were incubated for $6 \mathrm{~h}$ at room temperature with the peroxidase-labeled anti-rabbit IgG antibody $(1: 20,000)$. Staining was achieved by incubating the sections in Tris- $\mathrm{HCl}(20 \mathrm{mM}, \mathrm{pH}$ 7.8) containing $0.2 \mathrm{mg} / \mathrm{mL}$ DAB and $0.0036 \% \mathrm{H}_{2} \mathrm{O}_{2}$ ( $\mathrm{vol} / \mathrm{vol}$ ). Negative controls were obtained by replacing primary antibodies with nonimmune serum. The number and sizes of cells immunoreactive for prolactin and $\mathrm{GH}$ were assessed using a $\times 100$ objective lens within an ocular micrometer.

Pituitary perifusion experiments. In each experiment, the pituitaries from three wild-type males and three homozygous males were perifused simultaneously. Immediately after excision, pituitaries were washed in perifusion chambers $(0.5 \mathrm{~mL}$ volume) for $30 \mathrm{~min}$ at $37^{\circ} \mathrm{C}$ in oxygenated Dulbecco's modified Eagle's medium (with L-glutamine, $4.5 \mathrm{~g} / \mathrm{L}$ glucose, 25 $\mathrm{mM}$ HEPES) containing $0.1 \% \mathrm{BSA}$, and superfused at a rate of $0.1 \mathrm{~mL} / \mathrm{min}$ with the same medium. After a 120 -min equilibration period, effluents were collected every $5 \mathrm{~min}$. Mouse GHRH (Phoenix Pharmaceuticals, Belmont, CA, U.S.A.; $10^{-7}$ $\mathrm{M})$ and $0.03 \mathrm{M} \mathrm{KCl}$ was added to the medium for 15 - and 20-min periods, respectively, separated by perifusion with medium alone. Samples were frozen until GH determination.

Pituitary extracts. After excision, pituitary glands were frozen in liquid nitrogen and stored at $-80^{\circ} \mathrm{C}$. Extracts were obtained by sonication in $0.1 \mathrm{M} \mathrm{NaHCO}_{3}$, followed by centrifugation to remove tissue debris. The Bradford assay (BioRad protein assay, Munich, Germany) was used to determine protein concentration, using BSA as the standard.

$\boldsymbol{G H} \boldsymbol{R I A}$. GH concentrations in pituitary extracts and perifusion media were determined by RIA using reactants developed and generously provided by A.F. Parlow (Harbor-UCLA Medical Center, Torrance, CA, U.S.A.). Purified mouse GH preparations were used for iodination by the chloramine $\mathrm{T}$ method and for the standard curves. Anti-rat GH antibody was used at 1:3,200,000 final dilution. Samples were studied at three dilutions, each in duplicate. Incubation was conducted for $3 \mathrm{~d}$ at $4{ }^{\circ} \mathrm{C}$ in a total volume of $800 \mu \mathrm{L}$ in $0.01 \mathrm{M}$ PBS, $0.25 \%$ BSA, and 0.01 M EDTA. Separation of bound and free hormone was achieved by immunoprecipitation using polyethylene glycol and bovine immunoglobulin. Intra- and interassay variations were approximately $3 \%$ and $10 \%$, respectively.

Plasma IGF-I assay. This was performed as previously reported (1). Briefly, 25- $\mu \mathrm{L}$ samples were incubated in $0.01 \mathrm{M}$ $\mathrm{HCl}$ and ultrafiltered on Centricon 30 (Amicon, Epernon, France) to dissociate and separate IGFs from IGFBPs. IGF recovery is close to $100 \%$ in the ultrafiltrate in which neither IGFBPs nor their proteolytic fragments are detectable (8). The ultrafiltrates were lyophilized, then taken up in $0.1 \mathrm{M}$ phosphate buffer, $0.1 \% \mathrm{BSA}$, and incubated for $3 \mathrm{~d}$ at $4{ }^{\circ} \mathrm{C}$ in a final 
volume of $400 \mu \mathrm{L}$ with ${ }^{125}$ I-IGF-I and a polyclonal anti-hIGF-I antibody $(1: 100,000)$ that cross-reacts with murine IGF-I. The standard curve was established with the same preparation of recombinant hIGF-I as that used for iodination. Unknown samples were tested at two concentrations plus one blank (without antibody), each in duplicate. After incubation, free and bound IGFs were separated using albumin-coated charcoal. Intraassay variation was less than $5 \%$ and interassay variation, $10 \%$.

Statistics. Conventional methods were used for comparisons of the means (Student's $t$ and Mann-Whitney $U$ tests) and linear regression analysis. Probability values $\leq 0.05$ were regarded as significant.

\section{RESULTS}

GH content of pituitary glands. The pituitary glands of homozygous transgenic mice were decreased in weight approximately proportionally with their body weights, as compared with wild-type siblings (Table 1). Figure 1 shows the GH content of the pituitaries of heterozygous, homozygous, and wild-type mice. Although the values were widely dispersed in both transgenic and wild-type animals, on average they were higher in males than in females, the means for heterozygotes were significantly lower than those for wild types, and the means for homozygotes were significantly lower than those for heterozygotes. There was nevertheless a positive correlation between GH values and total protein content (Fig. 2), and the ratios of $\mathrm{GH} /$ total protein were of the same order of magnitude in transgenic and wild-type mice (Table 2).

Immunocytochemistry. Compared with those in wild-type animals, the somatotrophs and lactotrophs of homozygotes appeared of normal size, but density was reduced (Fig. 3). There was no significant difference between males $(n=3)$ and females $(n=4)$. For all the hypophyses examined, the number of somatotrophs in the same area was decreased by $28 \%$ (41 \pm 2 versus $57 \pm 3$ per $19,000 \mu \mathrm{m}^{2}$ surface area in wild types, $p$ $=0.001)$ and that of lactotrophs, by $35 \%(42 \pm 2$ versus $66 \pm$ 1 per $19,000 \mu \mathrm{m}^{2}$ surface area in wild types, $p=0.0001$ ).

The observation of reduced cell population but normal GH/ total protein ratio would indicate in vivo stimulation of $\mathrm{GH}$ secretion. It was therefore necessary to assess the secretory capacity of the pituitary glands.

Perifusion of the pituitary glands. The results shown in Figure 4 represent the GH secretion profiles in vitro by pituitaries of male homozygotes and wild-type mice (means for three pituitaries in the same experiment). The quantities of GH secreted were similar, both under basal conditions and under

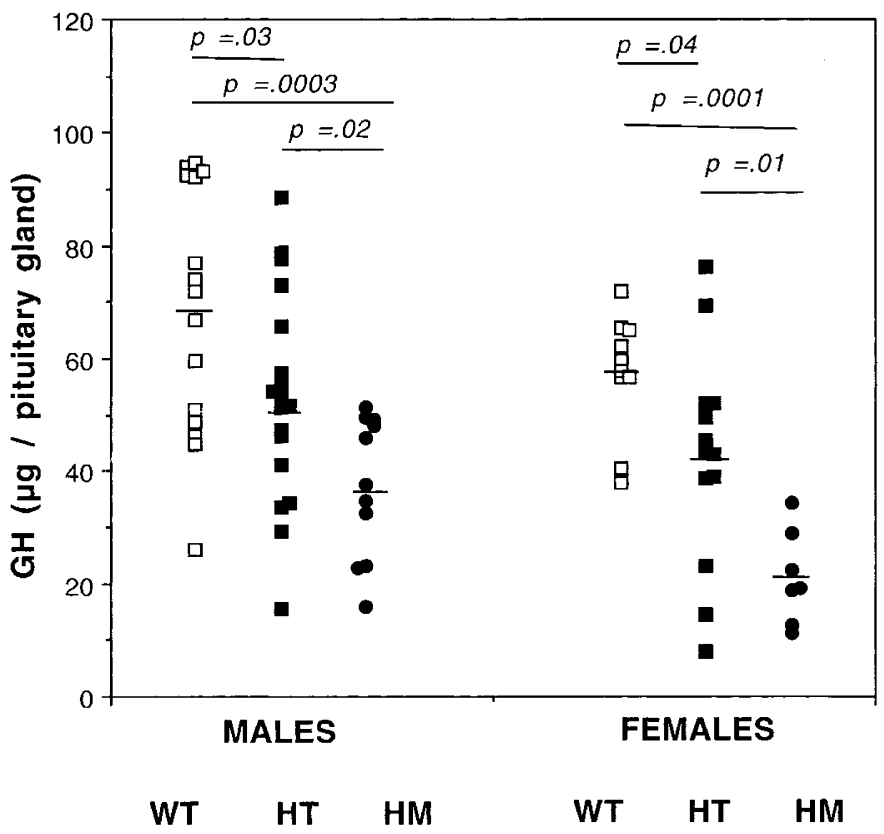

Figure 1. GH content of the pituitary glands of heterozygous $(H T)$ and homozygous (HM) IGFBP-1 transgenic and wild-type (WT) mice aged 3-4 mo ( $p$ values obtained using the $t$ test).

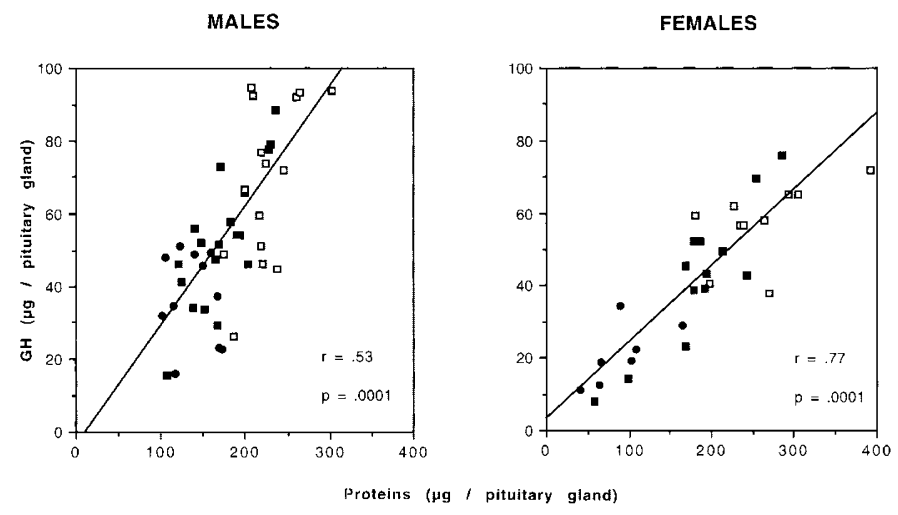

Figure 2. $\mathrm{GH}$ as related to total protein content in the pituitary glands of IGFBP-1 transgenic mice ( homozygotes, $\square$ heterozygotes) and wild types (口).

stimulation. The means of the cumulative GH concentrations in the eluates collected between 35 and 80 min of perifusion, corresponding to the peaks induced by GHRH, were $1384 \pm$ $128 \mathrm{ng}( \pm \mathrm{SEM})$ for $500 \mu \mathrm{L}$ in wild types and $1385 \pm 296 \mathrm{ng}$ in homozygotes. The means for the cumulative concentrations corresponding to the peaks induced by potassium depolarization (eluates collected between 85 and 130 min of perifusion)

Table 1. Body and pituitary weights of 6-mo-old wild-type and IGFBP-1 transgenic mice

\begin{tabular}{lccc}
\hline & $\begin{array}{c}\text { Wild types } \\
(n=7)\end{array}$ & $\begin{array}{c}\text { Heterozygotes } \\
(n=6)\end{array}$ & $\begin{array}{c}\text { Homozygotes } \\
(n=11)\end{array}$ \\
\hline Body weight $(\mathrm{g})$ & $35.4 \pm 1.8$ & $32.8 \pm 3.4$ & $26.8 \pm 0.6^{*}$ \\
Pituitary weight $(\mathrm{mg})$ & $1.90 \pm 0.18$ & $1.62 \pm 0.11$ & $1.30 \pm 0.08^{* *}$ \\
Pituitary weight $(\mathrm{mg}) /$ body weight $(\mathrm{g}) \times 100$ & $5.34 \pm 0.45$ & $4.75 \pm 0.62$ & $4.94 \pm 0.37$ \\
\hline
\end{tabular}

Results are mean \pm SEM.

$* p=0.002$ versus heterozygotes and 0.0001 versus wild types (Student's $t$ test).

${ }^{* *} p=0.03$ versus heterozygotes and 0.002 versus wild types (Student's $t$ test). 
Table 2. GH to total protein ratio in the pituitary glands of homozygous and heterozygous IGFBP-1 transgenic and wild-type

\begin{tabular}{ccc}
\multicolumn{3}{c}{ mice } \\
\hline & Males & Females \\
\hline HM & $0.28 \pm 0.03$ & $0.24 \pm 0.03$ \\
HT & $0.30 \pm 0.02$ & $0.21 \pm 0.02$ \\
WT & $0.30 \pm 0.02$ & $0.23 \pm 0.02$ \\
\hline
\end{tabular}

Results are mean \pm SEM.

Abbreviations used: HM, homozygous; HT, heterozygous; WT, wild type.

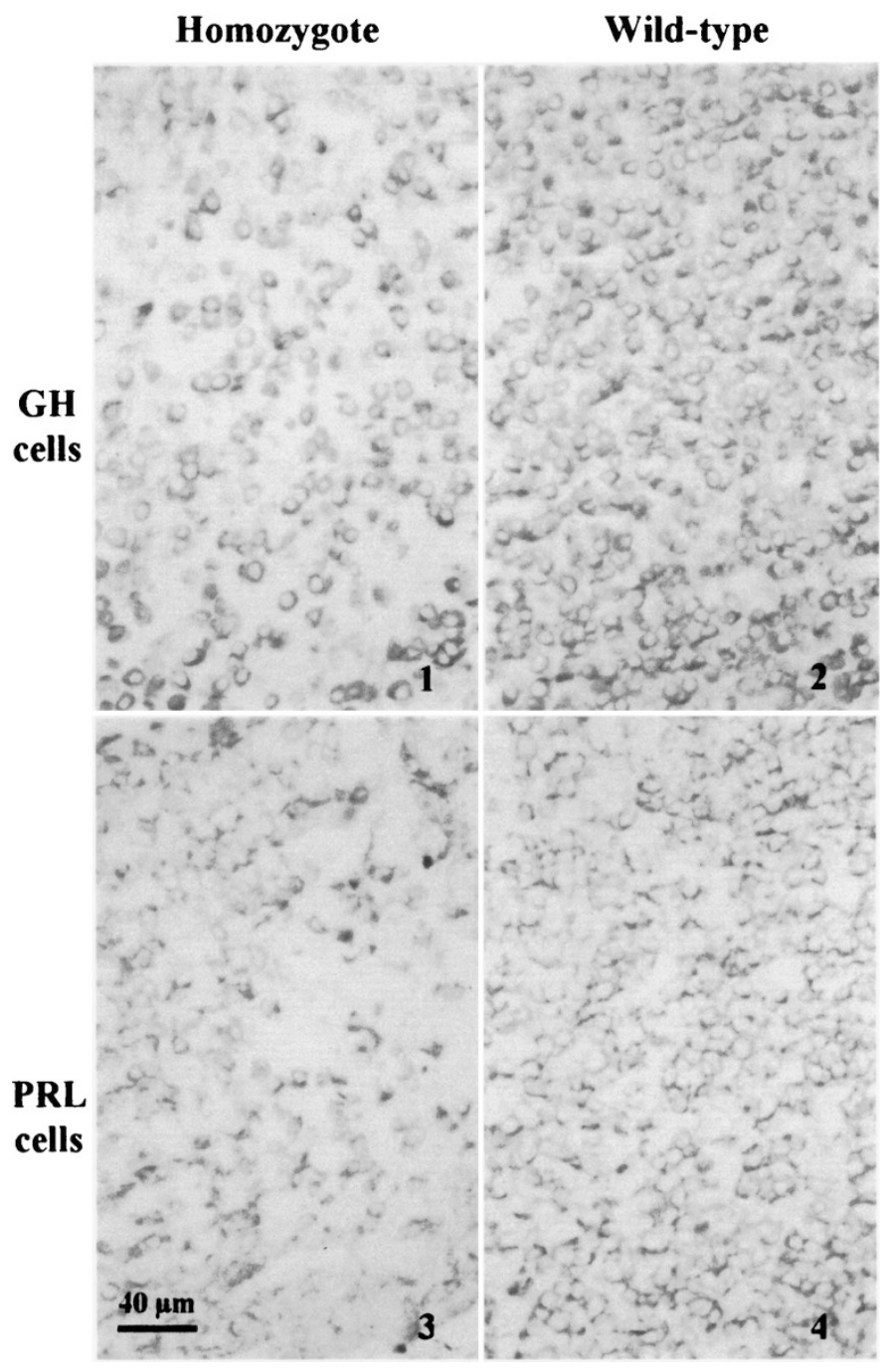

Figure 3. GH- and prolactin (PRL) immunoreactive cells in the pituitaries of adult homozygous IGFBP-1 transgenic and wild-type mice. Original magnification $\times 400$. Cell size was similar in the two groups, but the number of somatotrophs per 19,000 $\mu^{2}$ surface area was $41 \pm 2$ in homozygotes $(n=$ 7 pituitaries), as opposed to $57 \pm 3$ in wild types $(n=6, p=0.001)$, and the number of lactotrophs was $42 \pm 2$ in homozygotes $(n=6)$, as opposed to 66 \pm 1 in wild types $(n=6, p=0.0001)(t$ test $)$.

were $3924 \pm 293 \mathrm{ng}$ for $500 \mu \mathrm{L}$ in wild types and $4497 \pm 773$ ng in homozygotes.

$\boldsymbol{h G H}$ treatment. Forty-five-day-old transgenic and wild-type mice were treated simultaneously for a period of $10 \mathrm{~d}$ (with a break at d 6). hGH was administered by i.p. injection (50 $\mu \mathrm{g}$ in saline solution) twice daily, yielding a total dosage of $900 \mu \mathrm{g}$. Controls consisted of wild-type mice treated in parallel with saline solution.

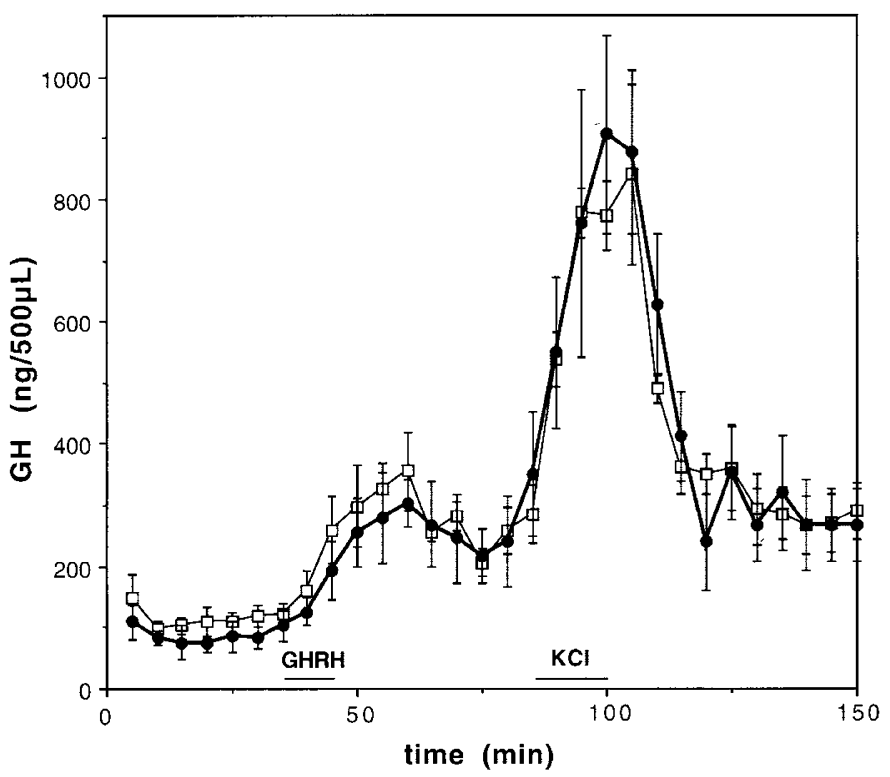

Figure 4. GH secretion by pituitary glands of male homozygous IGFBP-1 transgenic $(\bullet)$ and wild-type $(\square)$ mice superfused at $0.1 \mathrm{~mL} / \mathrm{min}$ in perifusion chambers. Effluents were collected every $5 \mathrm{~min}$ for GH measurement. Mouse GHRH $\left(10^{-7} \mathrm{M}\right)$ was added to the medium for $15 \mathrm{~min}$ and $\mathrm{KCl}(0.03 \mathrm{M})$ for $20 \mathrm{~min}$. Each curve represents the means of secretion by three pituitaries in the same experiment. Similar results were obtained in another experiment.

The curves for weight gain presented in Figure 5 show an acceleration of growth during GH treatment, which was modest in wild types and more pronounced in homozygotes and heterozygotes, followed by slower growth after the end of treatment. Figure 6 shows the means $( \pm$ SEM $)$ of the percentage weight increases between the beginning and end of treatment ( $24 \mathrm{~h}$ after the last injection), compared with those for

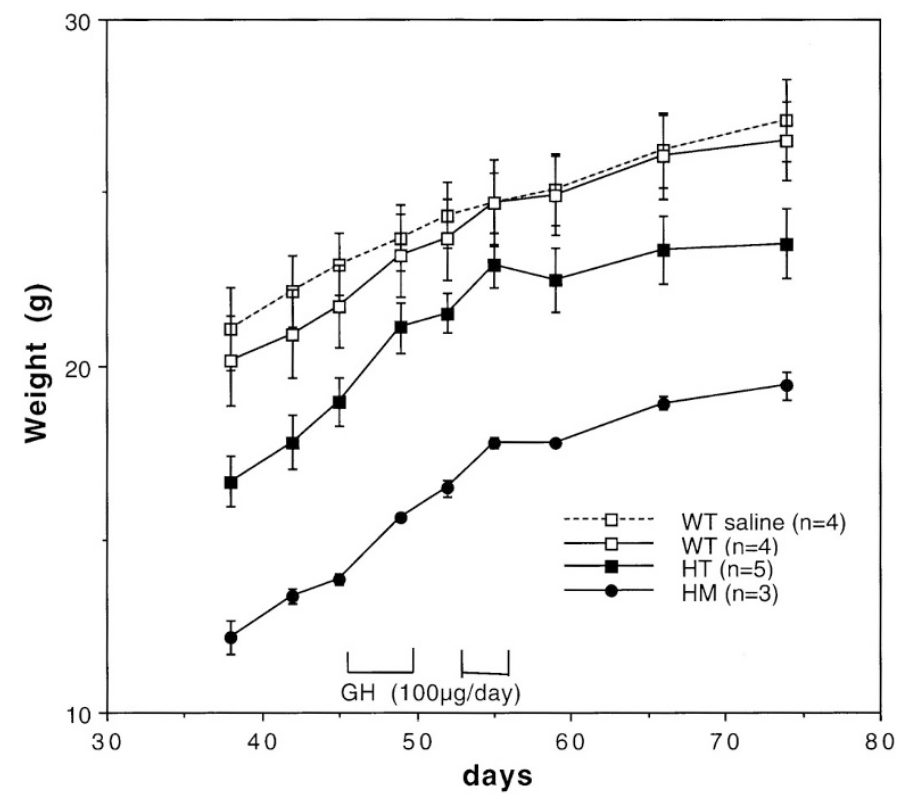

Figure 5. Weight curves for IGFBP-1 transgenic mice (homozygotes, $H M$; heterozygotes, $H T$ ) and wild types $(W T)$ treated from the age of $45 \mathrm{~d}$ with human GH for a period of $10 \mathrm{~d}$. Numbers of animals per group are indicated in parentheses. Wild-type controls were treated with saline solution (vehicle). 
untreated animals of the same age. Among untreated animals, mean weight gain was lesser in wild types than in heterozygotes and homozygotes, the weights of which at the age of $45 \mathrm{~d}$ were considerably lower than those of wild types (Fig. 5). Injection of saline (vehicle) in control wild types had no effect on growth. Weight gain with GH treatment was $28.5 \pm 0.5 \%$ in homozygotes, as compared with $20.7 \pm 2.9 \%$ in heterozygotes $(p=0.025)$ and $13.7 \pm 0.8 \%$ in wild types $(p=0.001)$. In all three treated groups, growth stimulation by $\mathrm{GH}$ was significant $(p \leq 0.02)$ when compared with the spontaneous growth of untreated animals. After subtracting the weight gain of untreated mice, growth that could be attributed specifically to $\mathrm{GH}$ treatment was on average $12.4 \%$ in homozygotes and $10.4 \%$ in heterozygotes, as opposed to $5.8 \%$ in wild types.

Plasma IGF-I was assayed before and $24 \mathrm{~h}$ after GH treatment. These levels (in nanograms per milliliter) are shown in Figure 7. Calculations of percent variation showed that in wild types injected with saline solution, there was minimal change $(-7$ to $+14 \%)$. In GH-treated wild types, IGF-I increased in two of four cases $(+33$ and $+47 \%)$. Among heterozygotes, four of five of which had basal IGF-I levels at the lower limit or below those of corresponding wild types, plasma IGF-I after GH treatment remained stable in the mouse with the highest basal level and in the others, it increased $(28 \%, 53 \%, 154 \%$, and $457 \%$ ). In the three homozygotes investigated, plasma IGF-I before treatment was below that of wild types and rose after treatment by $19 \%, 43 \%$, and $92 \%$. Statistical analysis revealed a significant difference in IGF-I levels before and after treatment in heterozygotes $(p=0.025)$ and in the transgenic mice (heterozygous and homozygous) taken as a group ( $p=$

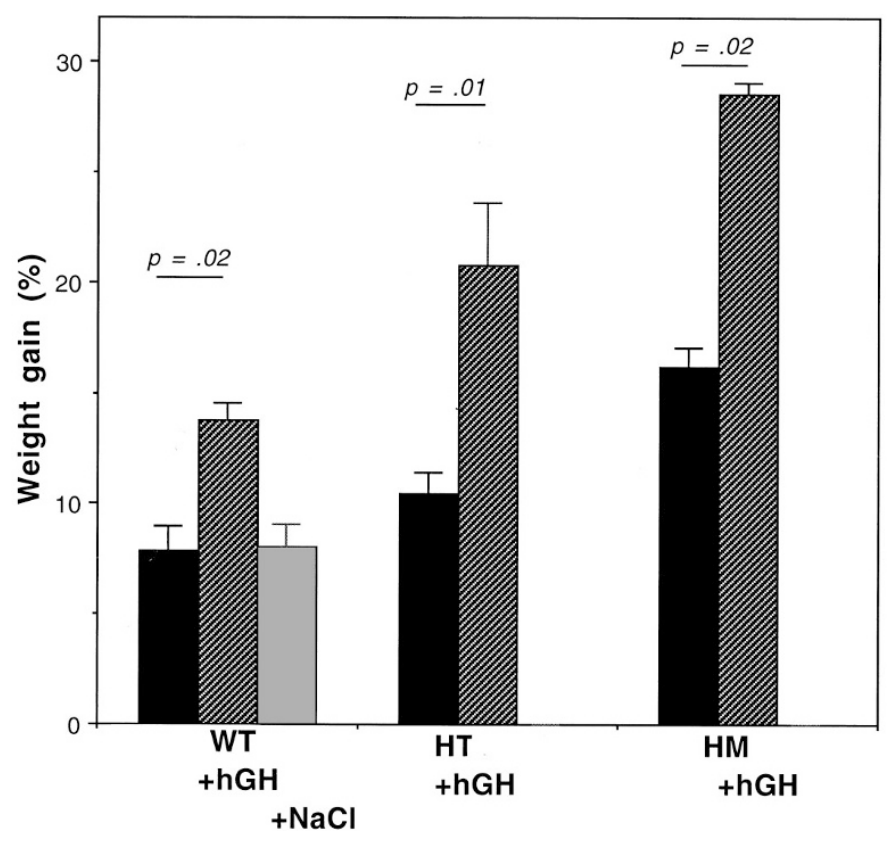

Figure 6. Mean weight gain in GH-treated transgenic (homozygotes, HM; heterozygotes, $H T$ ) and wild-type (WT) mice (hatched bars). Wild-type controls were treated with saline (shaded bar). The means are compared with those for untreated animals of the same age (filled bars). Weight gain was calculated on the basis of the difference between weight at the beginning and $24 \mathrm{~h}$ after the end of treatment as a percentage of weight at the beginning of treatment ( $p$ values obtained using the Mann-Whitney $U$ test).

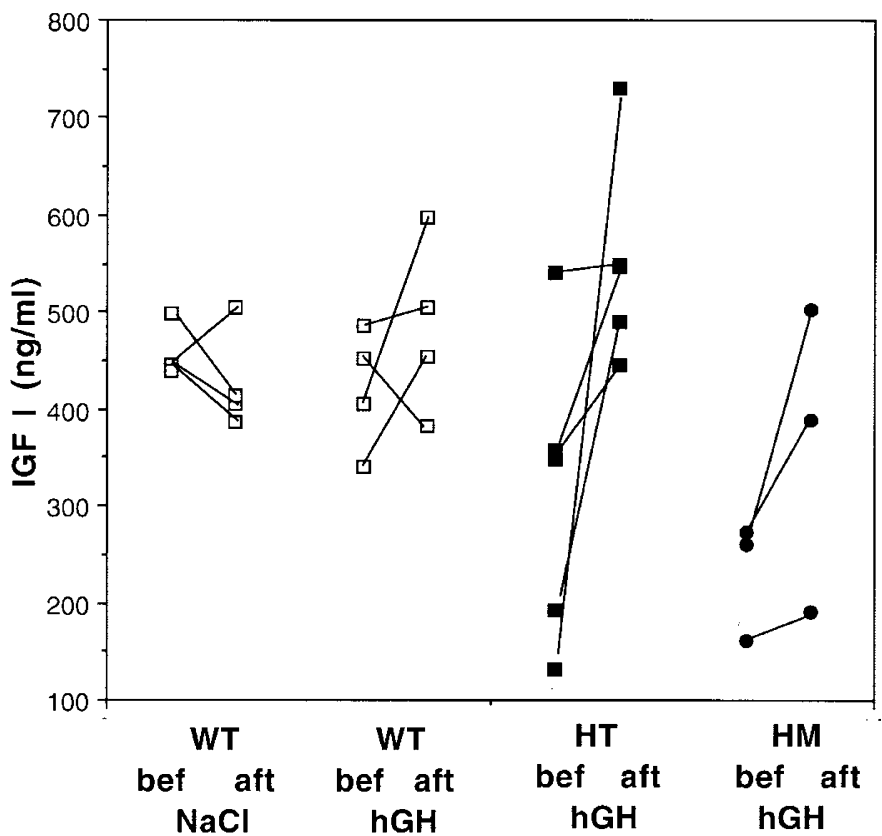

Figure 7. Plasma IGF-I levels in mice before (bef) and $24 \mathrm{~h}$ after the end of (aft) GH treatment (wild types, WT; heterozygotes, HT; homozygotes, $H M$ ). $\mathrm{NaCl}$, wild-type mice injected with saline solution.

$0.015, t$ test). For all animals, it appeared that there was a relationship between percentage weight gain and IGF-I levels, as suggested by the correlation between the two variables when the two extreme increases of $154 \%$ and $457 \%$ were excluded $(r$ $=0.56, p=0.002$, not shown).

\section{DISCUSSION}

In this line of transgenic mice with liver-specific hIGFBP-1 expression, investigation of the cause of the drop in plasma IGF-I levels and its effects on growth restriction revealed a $28 \%$ reduction in somatotroph density in the pituitary glands of homozygotes, as compared with wild-type animals. However, assays of pituitary GH content showed that the GH/total protein ratios in transgenics and wild types were similar. This would suggest increased GH synthesis by the smaller somatotroph population, which reflects an appropriate response of the hypothalamo-pituitary system to the sequestration of free IGF-I by excess IGFBP-1. The perifusion experiments indicated that there was little difference between transgenics and controls in the amounts of GH secreted in vitro under basal or GHRH-stimulated conditions. In the absence of specific antibody, we were unable to measure the GHRH content of hypothalami. Nevertheless, the data for pituitary GH content and $\mathrm{GH} /$ total protein ratios indicate that the somatotrophs must be stimulated by GHRH in vivo.

Plasma GH levels had been measured in mice of this line during the earlier study. No difference was found between transgenics and wild types (9). However, these measurements are not informative regarding production in the pituitary, $\mathrm{GH}$ clearance being rapid, unlike that of IGF-I (3). The fact that plasma IGF-I levels in homozygous males were only half those of wild types (1) means that hepatic production of IGF-I was defective. Moreover, the negative correlation seen between 
IGF-I and IGFBP-1 levels in adult heterozygous and homozygous animals (1) clearly demonstrated the link between IGF-I levels and transgene expression.

It seemed possible that IGFBP-1 could directly inhibit IGF-I synthesis in the liver, inasmuch as both peptides are produced by hepatocytes (6). However, from the tests using GH treatment, which provoked a rise in plasma IGF-I and a marked acceleration of growth in transgenics, it is evident that their hepatocytes responded normally to their physiologic stimulus and that inhibition by IGFBP-1 is unlikely. It could therefore be concluded that insufficient GH production may account for the diminished IGF-I levels. The reduced population of somatotrophs could explain this. However, because the pituitary glands of homozygotes were capable of secreting as much GH in vitro as the wild-type counterparts, the question arises of a functional alteration of hypothalamic control that would result in insufficient production of GH in vivo. Circumstantial evidence would plead in favor of hypothalamo-pituitary dysfunction: 1) the more pronounced growth retardation in homozygous males than in females (1) suggests a decrease in the frequency or amplitude of GH pulses, which are characteristic of the sexual dimorphism of the somatotrophic axis (10); and 2) homozygotes exhibit reproductive abnormalities associated with severe alteration of ovulation in transgenic females. $\mathrm{LH}$ levels in the pituitaries of homozygotes have recently been shown to be more than eight times higher than those in wild types. This is accompanied by a slight increase in the number of LH-gonadotrophs and a reduction in their size, which would suggest some alteration of the pulsatile secretion of LH (P. Froment et al., manuscript in preparation).

The reduced numbers of GH- and prolactin-producing cells would point toward a disturbance in adenohypophyseal development, associated with the other anomalies of the CNS observed in these transgenic mice (7). Somatotrophic and lactotrophic changes have been reported in a line of mice with a disrupted IGF-I gene, in which GH cell size, but not number, is significantly reduced, with a GH RNA signal stronger than in controls. In contrast, the number of lactotrophs and the prolactin hybridization signal are significantly diminished (11). Despite the differences, the abnormalities described in these two models of transgenic mice suggest that IGF-I is involved in the development of the adenohypophysis. Also, hypertrophy and hyperplasia of somatotrophs have been reported in transgenic mice overexpressing GHRH (12). Interestingly, reduced plasma GH and prolactin levels, decreased size and increased number of LH immunoreactive cells, and increased LH concentration in the pituitary have also been observed in streptozotocin-induced diabetic rats $(13,14)$, suggesting a similar alteration of the hypothalamo-pituitary axis.

The results of this study therefore indicate that insufficient GH production is implicated in the growth restriction of our transgenic mice. In two other models of IGFBP-1 transgenic mice obtained using the ubiquitous metallothionein (15) or phosphoglycerate kinase (16) promoters, growth retardation was observed only in the latter and the somatotrophic axis was not investigated. In our model, it is noteworthy that the initial disturbance responsible for the anomalies is overexpression of IGFBP-1 at its normal site of synthesis, the liver. The excess
IGFBP-1 provided via the bloodstream to the adenohypophysis and to the CNS before the blood-brain barrier becomes functional may alter their development either by some intrinsic action at the cellular level or, more probably, by reducing IGF bioavailability.

It is tempting to draw a comparison between the changes in the somatotrophic axis in this model with those reported in intrauterine growth restriction in the rat and in man, in which the complex pathophysiology is governed by both maternal and fetal factors. Here, low IGF-I and high IGFBP-1 serum levels have been observed in the fetus and at birth (17-21). In children with persistent postnatal growth retardation, diminished spontaneous secretion of GH $(22,23)$ constitutes the rationale for GH treatment $(24,25)$.

Acknowledgment. The authors thank Pierre Casanovas for technical assistance.

\section{REFERENCES}

1. Gay E, Seurin D, Babajko S, Doublier S, Cazillis M, Binoux M 1997 Liver-specific expression of human insulin-like growth factor binding protein-1 in transgenic mice: repercussions on reproduction, ante- and perinatal mortality and postnatal growth. Endocrinology 138:2937-2947

2. Lee PDK, Giudice LC, Conover CCA, Powell DR 1997 Insulin-like growth factor binding protein-1: recent findings and new directions. Proc Soc Exp Biol Med 216:319-357

3. Rajaram S, Baylink DJ, Mohan S 1997 Insulin-like growth factor binding proteins in serum and other biological fluids: regulation and functions. Endocr Rev 18:801-831

4. Lewitt MS, Saunders H, Phuyal JL, Baxter RC 1994 Complex formation by human insulin-like growth factor binding protein-3 and human acid-labile subunit in growth hormone-deficient rats. Endocrinology 134:2404-2409

5. Giustina A, Veldhuis JD 1998 Pathophysiology of the neuroregulation of growth hormone secretion in experimental animals and the human. Endocr Rev 19:717-797

6. Rechler MM, Nissley SP 1990 Insulin-like growth factors. In: Sporn MB, Roberts AB (eds) Peptide Growth Factors and Their Receptors. Springer Verlag, Berlin, pp 263-367

7. Doublier S, Duyckaerts C, Seurin D, Binoux M 2000 Impaired brain development and hydrocephalus in a line of transgenic mice with liver-specific expression of human insulin-like growth factor binding protein-1. Growth Hormone IGF Res 10:267-274

8. Lassarre C, Binoux M 2001 Measurement of intact insulin-like growth factor binding protein-3 in human plasma using a ligand immunofunctional assay. J Clin Endocrinol Metab 85:1260-1266

9. Doublier S, Seurin D, Fouqueray B, Verpont MC, Callard P, Striker LJ, Striker GE, Binoux M, Baud L 2000 Glomerulosclerosis in mice transgenic for human insulinlike growth factor binding protein-1. Kidney Int 57:2299-2307

10. Gatford KL, Egan AR, Clarke IJ, Owens PC 1998 Sexual dimorphism of the somatotrophic axis. J Endocrinol 157:373-389

11. Stefaneanu L, Powell-Braxton L, Won W, Chandrashekar V, Bartke A 1999 Somatotroph and lactotroph changes in the adenohypophyses of mice with disrupted insulin-like growth factor I gene. Endocrinology 140:3881-3889

12. Stefaneanu L, Kovacks K, Horvath E, Asa SL, Losinski NE, Billestrup N, Price J, Vale W 1989 Adenohypophysial changes in mice transgenic for human growth hormone-releasing factor: a histological, immunocytochemical, and electron microscopic investigation. Endocrinology 125:2710-2718

13. Boujon CE, Bestetti GE, Abramo F, Locatelli V, Rossi GL 1995 The reduction of circulating growth hormone and prolactin in streptozotocin-induced diabetic male rats is possibly caused by hypothalamic rather than pituitary changes. J Endocrinol $145: 19-27$

14. Dong Q, Lazarus RM, Wong LS, Vellios M, Handelsman DJ 1991 Pulsatile LH secretion in streptozotocin-induced diabetes in the rat. J Endocrinol 131:49-55

15. Dai Z, Xing Y, Boney CM, Clemmons DR, D’Ercole AJ 1994 Human insulin-like growth factor binding protein-1 (IGFBP-1) in transgenic mice: characterization and insights into the regulation of IGFBP-1 expression. Endocrinology 135:1316-1327

16. Rajkumar K, Barron D, Lewitt MS, Murphy LJ 1995 Growth retardation and hyperglycemia in insulin-like growth factor binding protein-1 transgenic mice. Endocrinology 136:4029-4034

17. Unterman T, Lacson R, Gotway MB, Oehler D, Gounis A, Simmons RA, Ogata ES 1990 Circulating levels of insulin-like growth factor binding protein-1 (IGFBP-1) and hepatic mRNA are increased in the small for gestational age (SGA) fetal rat. Endocrinology 127:2035-2037

18. Strauss DS, Ooi GT, Orlowski CC, Rechler MM 1991 Expression of the genes for insulin-like growth factor-I (IGF-) and IGF binding proteins-1 and - 2 in fetal rat under conditions of intrauterine growth retardation caused by maternal fasting. Endocrinology 128:518-525

19. Lassarre C, Hardouin S, Daffos F, Forestier F, Frankenne F, Binoux M 1991 Serum insulin-like growth factors and insulin-like growth factor binding proteins in the 
human fetus: relationships with growth in normal subjects and in subjects with intrauterine growth retardation. Pediatr Res 29:219-225

20. Verhaeghe J, van Bree R, van Erck E, Laureys J, Bouillon R, van Assche FA 1993 C-peptide, insulin-like growth factor I and II and insulin-like growth factor binding protein-1 in umbilical cord serum: correlations with birth weight. Am J Obstet Gynecol 159:89-97

21. Giudice LC, De Zegher F, Gargosky SE, Dsupin BA, de las Fuentes L, Crystal RA, Hintz RL, Rosenfeld RG 1995 Insulin-like growth factors and their binding proteins in the term and preterm human fetus and neonate with normal and extremes of intrauterine growth. J Clin Endocrinol Metab 80:1548-1555

22. De Waal WK, Hokken-Koelega AC, Stijnen T, De Muinck Keizer-Schrama SM, Drop SL 1994 Endogenous and stimulated GH secretion, urinary GH excretion, and plasma IGF-I and IGF-II levels in prepubertal children with short stature after intrauterine growth retardation. Clin Endocrinol 41:621-630

23. Boguszewski M, Rosberg S, Albertsson-Wikland K 1995 Spontaneous 24-hour growth hormone profiles in prepubertal small for gestational age children. J Clin Endocrinol Metab 80:2599-2606

24. Chernausek SD, Breen TJ, Frank GR 1996 Linear growth in response to growth hormone in children with short stature associated with intrauterine growth retardation: the national cooperative growth study experience. J Pediatr 122(suppl):S22S27

25. De Zegher F, François I, van Helvoirt M, van de Berghe G 1997 Small as fetus and short as child: from endogenous to exogenous growth hormone. J Clin Endocrinol Metab 82:2021-2026 